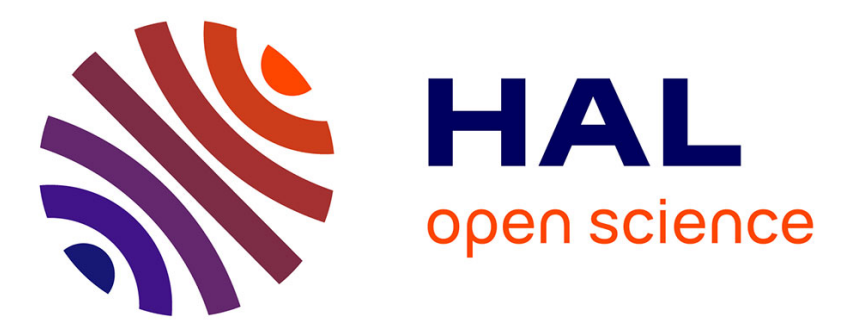

\title{
French software politics: activism and the dynamics of globalization from below
}

Pierre-Amiel Giraud, Sara Schoonmaker

\section{To cite this version:}

Pierre-Amiel Giraud, Sara Schoonmaker. French software politics: activism and the dynamics of globalization from below. RESI - Revista Eletrônica de Sistemas de Informação, 2014, 13 (2), pp.3. 10.5329/RESI.2014.1302003 . halshs-01531813

\section{HAL Id: halshs-01531813 \\ https://shs.hal.science/halshs-01531813}

Submitted on 2 Jun 2017

HAL is a multi-disciplinary open access archive for the deposit and dissemination of scientific research documents, whether they are published or not. The documents may come from teaching and research institutions in France or abroad, or from public or private research centers.
L'archive ouverte pluridisciplinaire HAL, est destinée au dépôt et à la diffusion de documents scientifiques de niveau recherche, publiés ou non, émanant des établissements d'enseignement et de recherche français ou étrangers, des laboratoires publics ou privés.

\section{(c)(1)}

Distributed under a Creative Commons Attribution| 4.0 International License 


\section{Revista Eletrônica de Sistemas de Informação ISSN 1677-3071}

\section{v. 13 , n. 2}

\section{May-Ago 2014 - special issue on FOSS}

doi:10.5329/RESI.2014.1302

\section{Editor's space}

Editorial

Carlos Denner dos Santos Jr.

\section{Essays}

RIO IN THE GLOBAL WORLD OF SOFTWARE Yuri Takhteyev

\section{Free software}

THE ALGORITHMIC AUTOREGULATION SOFTWARE DEVELOPMENT METHODOLOGY

Renato Fabbri, Ricardo Fabbri, Vilson Vieira, Daniel Penalva, Danilo Shiga, Marcos Mendonça,

Alexandre Negrão, Lucas Zambianchi, Gabriela Salvador Thumé

FRENCH SOFTWARE POLITICS: ACTIVISM AND THE DYNAMICS OF GLOBALIZATION FROM BELOW

Pierre-Amiel Giraud, Sara Schoonmaker

O USO DO SOFTWARE LIVRE NA NA APRENDIZAGEM COLABORATIVA: LIMITES E POSSIBILIDADES

DO PROGRAMA "UM COMPUTADOR POR ALUNO"

Rafaela da Silva Melo, Ana Beatriz Gomes Pimenta de Carvalho

HISTORICAL ANALYSIS OF MESSAGE CONTENTS TO RECOMMEND ISSUES TO OPEN SOURCE SOFTWARE CONTRIBUTORS

Igor Fabio Steinmacher, Igor S Wiese, Andre Luis Schwerz, Rafael Liberato Roberto, João Eduardo Ferreira, Marco Aurélio Gerosa

SENTIMENT ANALYSIS OF FREE/OPEN SOURCE DEVELOPERS: PRELIMINARY FINDINGS FROM A CASE STUDY

Athanasios-Ilias Rousinopoulos, Gregorio Robles, Jesús M. González-Barahona

ESTUDIO PRELIMINAR DE LAS EMPRESAS QUE MÁS CONTRIBUYEN AL DESARROLLO DE ANDROID

Sergio Raul Montes León, José David Ramos Benalcazar, Hernán Montes León

\section{(c) $\overline{E Y}$}

This work is licensed under a Creative Commons Attribution 3.0 License. 
Esta revista é (e sempre foi) eletrônica para ajudar a proteger o meio ambiente, mas, caso deseje imprimir esse artigo, saiba que ele foi editorado com uma fonte mais ecológica, a Eco Sans, que gasta menos tinta.

This journal is (and has always been) electronic in order to be more environmentally friendly. Now, it is desktop edited in a single column to be easier to read on the screen. However, if you wish to print this paper, be aware that it uses Eco Sans, a printing font that reduces the amount of required ink. 


\title{
FRENCH SOFTWARE POLITICS: ACTIVISM AND THE DYNAMICS OF GLOBALIZATION FROM BELOW

\author{
POLITICA DE SOFTWARE DA FRANÇA: ATIVISMO E A DINÂMICA \\ DA GLOBALIZAÇÃO POR BAIXO
}

\author{
(artigo submetido em julho de 2013) \\ Pierre-Amiel Giraud \\ Doctorate student in Geography at the University Bordeaux Montaigne \\ pierre-amiel.giraudeu-bordeaux-montaigne.fr \\ Sara Schoonmaker \\ Professor of Sociology at the University of Redlands \\ Sara Schoonmakereredlands.edu
}

\begin{abstract}
In this paper, we explore how French Free Software activism can help to understand the dynamics of globalization from below. First, we explore the global context within which French Free Software activists built their community. They applied the approach of the global Free Software Foundation (FSF), which grounded its work in what we call the "freedom discourse." Through this discourse, FSF leaders articulated their goals and activities to emphasize the importance of software users and developers having access to source code. Equally important, they established Free Software as a new form of property that provided an alternative to the proprietary form. Second, we explore the development of the Free Software community in France. Since 1996, activists applied the freedom discourse to promote and defend Free Software as a new form of property. For the first five years they focused on public education work; however, after 2001 they mobilized to oppose two legislative initiatives that threatened Free Software by imposing digital rights management provisions. Finally, we reflect on how the case of French activists illuminates the dynamics of globalization from below. We highlight the contradictory ways that these activists forged links between local and global communities to create transboundary publics.
\end{abstract}

Key-words: Free software; activism; transboundary public; freedom discourse.

\section{RESUMO}

Neste artigo exploramos a forma como o ativismo do movimento pelo software livre na França pode ajudar a compreender a dinâmica da globalização por baixo. Inicialmente, exploramos o contexto no qua los ativistas do software livre na França construíram sua comunidade. Eles aplicaram a abordagem da Fundação de Software Livre - Free Software Foundation (FSF) -, que baseou o seu trabalho no que chamamos de "discurso de liberdade". Por meio desse discurso, os líderes do FSF articularam seus objetivos e atividades para enfatizar a importância de os usuários e desenvolvedores de software terem acesso ao código fonte. Igualmente importante, eles definiram o software livre com uma nova forma de propriedade que fornecia uma alternativa ao formato proprietário. A seguir, exploramos o desenvolvimento da comunidade do software livre na França. Desde 1996 os ativistas aplicam o discurso da Liberdade para promover e defender o software livre como uma nova forma de propriedade. Ao longo dos primeiros cinco anos eles se concentraram no trabalho de educação do público; contudo, a partir de 2001, se mobilizaram para fazer oposição ao duas iniciativas legislativas que ameaçavam o software livre ao definirem provisões para gestão dos direitos digitais. Por fim, refletimos sobre como o caso dos ativistas franceses ajuda a compreender a dinâmica da globalização de baixo. Destacamos as formas contraditórias como esses ativistas criaram ligações entre comunidades locais e globais para criar públicos que ultrapassam fronteiras.

Palavras-chave: software livre; ativismo; público transnacional; discurso de liberdade. 


\section{INTRODUCTION}

In the last few decades, neoliberalism arose as the dominant form of globalization. This "gradual spread of the liberal economic model over the world" (BOUQUET, 2007, p. 201) took place in parallel with the development of the digital economy, leading scholars to build the notion of informational capitalism (CASTELLS, 1996). Indeed, the 1990s were a time when American diplomacy promoted the idea of information superhighways, which in fact brought "higher levels of control and concentration in the global market" (SASSEN, 2005, p. 54).

This present form of globalization was preceded by another one, however, during which the model of the modern state spread throughout the world (GRATALOUP, 2007; MÉDARD, 2007). Its result can be seen in our typical picture of the world: a mosaic of states.

With the rise of neoliberalism, a consensus emerged among scholars that developing alternative forms of globalization is both possible and vital. For Sassen (2005, p. 54), such alternatives involve "distributive outcomes - greater participation of local organizations in global networks". They contribute to the development of "elementary forms of transboundary public spheres or forms of globality centered in multiple localized types of struggles and agency."

In this regard, free software activism offers a compelling example of the dynamics behind the emergence of these new forms of globality, what Kellner (2002) and others call "globalization from below." Indeed, Kelty (2008, p. 3) has shown that free software advocates constitute a "recursive public," that is to say, "a public that is vitally concerned with the material and practical maintenance and modification of the technical, legal, practical and conceptual means of its own existence as a public." Namely, they struggle to conserve, reinforce and spread the software through which they communicate, collaborate and coordinate. These "militants of code", as Couture and Proulx (2008) call them, view software code as a common good rather than as merchandise to be appropriated by corporations. They open new spaces of collective action, employing modes of participation where developers and users alike can cooperate to create software as a collective good. Such spaces of action are forms of social innovation that can potentially empower citizens, who live in local states. Complex intersections between local and global interests and actions are thus involved with the creation of such publics. In this paper, we prefer to speak about "transboundary publics" rather than "recursive publics." These are not mutually exclusive terms, but by doing so we intend to highlight the importance of the spatial context in which the freedom discourse is enunciated and received.

Thus, there are three main players in what we call "software politics": the neoliberal market, the modern state and the transboundary public of free software. Software politics is a key terrain of struggle over the politics of globalization due to the centrality of communication and information 
technologies in economic, political, cultural and social life. From a poststructural political economy perspective, understanding software politics involves identifying the complex political and economic interests involved in the software sector, as well as the discourses those interests employ to make their case for particular strategies.

Today, if not dominant, "state exclusive authority over its territory remains the prevalent mode of final authority in the global economy" (SASSEN, 2008, p. 416). Therefore, the global market and the transboundary public struggle to pressure the state to endorse their own discourse, and if possible to enforce it by law. These discourses are narratives of power and knowledge: through them, social actors draw upon cultural values that resonate with particular ways of understanding the social world and articulate their positions on the key issues at stake (FOUCAULT, 1978; SCHOONMAKER, 2002).

As a whole, the political economy of neoliberal globalization is accompanied by the drive to privatize property in many forms, including the contested notion of intellectual property. In the case of software politics, corporations (widely followed by governments) construct what we call a "proprietary discourse" that defines legal rules about software in order to protect the interests of private property. Conversely, free software activists elaborated what we call a "freedom discourse," which defends and promotes an alternative form of property that challenges the private property form. As an alternative to the dominant neoliberal globalization, free software appears as a mode of emergence (or re-emergence?) of the information commons (BOYLE, 2003). Thus, free software activists respond to the proprietary discourse by organizing to pressure the state. In this process of struggle between the two discourses, state power transforms legal arrangements that frame, and largely define, information and software.

Thereby, despite a broadly shared spatial and legal nature, states offer differentiated instances of the free software transboundary public. That is why we chose to study free software activism in a specific country. French free software activists provide an excellent case study because they have a strong history of political struggle. Since the 1990s, they have organized a broad range of projects and events. One of these events, the Rencontres Mondiales du Logiciel Libre (RMLL) (called the Libre Software Meeting or LSM in English), is the European equivalent to the Fórum Internacional do Software Livre. (GIRAUD, 2013; GIRAUD, forthcoming). Furthermore, Noonan, Baker and Moon (2008) affirm that the French free software community is one of the most dynamic in the world.

The main French free software organization is April (Association pour la promotion et la recherche en informatique libre or Association for promotion and research on free computing). In this paper, we explore two of its main early struggles: over the European Union Copyright Directive (EUCD) and over the Copyright and Related Rights in the Information Society (DADVSI) bill. Through these examples, we will explore two key propositions. 
First, we argue that the contradictory combination of the local and the global (or better yet, the political spatiality of the state and the economical spatiality of the market) constitutes a central dynamic involved with creating a transboundary public in the French case. This dynamic poses lessons for understanding the process of developing alternative forms of globality from below.

Second, exploring how activists organize to challenge the state (or often the market through the state) illuminates the dynamics of struggle against the process of neoliberal privatization in the information technology sector. We thus view free software as a way to address some of the problems involved with the privatization of the commons in a variety of fields.

The paper is organized into two parts. First, we explore the global context within which French free software activists built their community. Within their local context, they translated and transposed the freedom discourse of the Free Software Foundation (FSF). Through this discourse, which is the bedrock of their work, FSF leaders articulated their goals and activities to emphasize the importance of software users and developers having access to source code. Equally important, through the juridical instance of their discourse (i.e. the licenses), they established free software as a new form of property that provided an alternative to the proprietary form. Second, we explore the development and transformation of the free software community in France. Since 1996, they organized themselves and applied the freedom discourse to promote and defend free software as a new form of property. For the first five years, their discourse addressed the public at large, through educational work; however, after 2001, it shifted to the state. Indeed, they mobilized to oppose two legislative initiatives that threatened free software by imposing digital rights management provisions. In the conclusion, we reflect on how the case of French activists can help us understand the dynamics of globalization from below. We highlight the contradictory ways that these activists forged links between local and global communities to create transboundary publics.

\section{METHODS}

This paper is a collaboration between a French geographer and an American sociologist. We both employed a similar methodology before we met and began our collaboration, thus allowing us to compare our findings and develop a common understanding of our questions. Data for the paper include semi-structured interviews by Schoonmaker with four French activists from April, the Association pour la promotion et la recherche en informatique libre (or Association for promotion and research on free computing). Interview participants included April's founder and Executive Director; the President; a member of the Executive Board; and the Public Affairs officer. Interviews generally lasted between 45 and 90 minutes; they were recorded and transcribed. They were conducted in 2009 and 
2010. Giraud conducted semi-structured interviews with 21 people identified as close to the French Free Software movement, including members of April and a former advisor to the European deputy involved with debates about software patents. These interviews ranged from 35 to 130 minutes; four were done in 2010 and the rest in 2013. Interview participants were given a choice about whether they would be represented by a pseudonym to protect confidentiality.

Both authors also employed the ethnomethodological process of participant observation at major free software events in France. Schoonmaker engaged in this method at the Open World Forum of 2010 and 2011 and the Ubuntu download party in Paris in 2009. Giraud's participant observation took place at free software events where April took part, including the World Free Software Meetings of 2010 and 2012 and the Open World Forum in 2011 and 2012. April's strategies were discussed extensively in these venues. Giraud integrated a qualitative methodological approach with his personal knowledge of the workings of the Free Software movement and particularly April, of which he is a passive member.

In addition to this primary data, we drew upon secondary data about free software firms, users and activist groups that was available online, as part of networked communities where free software proponents create, respond to and share information. These websites and blogs were critical sites where free software proponents met to generate information about their perspectives and struggles. As such, they were very important embodiments of the freedom discourse. Cyberspace was one of the main research sites for this project; websites and blogs constituted what Karim (2003, p. 16) called "transnational third spaces" where actors engage creatively in tackling their problems. As Bernal (2006, p. 163) argued, such online interactions allow participants to "build upon existing social networks on the ground, bring them together and extend their membership and significance in novel ways". So, this third space, constituted of online freedom discourses, is where the transnational and recursive dimensions of free software publics are the most obvious. Our research methodology thus integrated ethnographic observation and interviewing 'on the ground' with a blend of online ethnography.

\section{THE FREEDOM DISCOURSE AND THE POLITICAL ECONOMY OF SOFTWARE}

French software politics developed in a global context where software developers and corporations struggled to create the political and economic conditions under which software would be developed and used. They engaged in these efforts through technical, legal and discursive means. Discourse was a key terrain on which these conflicts played out, as conflicting interests sought to define the terms under which software development took place. Certainly, the importance of discourse is magnified because the compilation of code, a veritable "scholarly practice" (DOUEIHI, 2008), is in itself discursive, taking place within a legal context which can be framed as a discourse negotiated and constructed 
through writing. The formalization of free software, through licensing, is thus constructed within a particular context of knowledge and power. Indeed, software developers understand that their work requires a degree of discursive mastery of the legal regime that regulates their practices.

French free software proponents primarily employed what we call the freedom discourse, which advocates two distinct kinds of freedom: the freedom for software developers to create a new form of property based upon a complex form of community ownership, rather than strictly private ownership; and the freedom for software users to access the software source code and to share it with each other. Thus, their discourse mobilizes two characters - the user and the developer - and a quasicharacter (RICOEUR, 1983; LUSSAULT, 2007) - the code - that act conjointly to liberate them all.

It is important to note that the freedom discourse articulates very different kinds of freedoms, for different kinds of actors, than the neoliberal discourse. As the discourse of the dominant form of globalization, the neoliberal discourse advocates the freedom of corporations to operate in global markets under whatever conditions are most profitable for them. In other words, this discourse presents freedom as an absence of juridical and administrative constraints, which results in the application of the preconceptions of deregulation that fit with the Washington consensus. Indeed, corporations and other proponents of neoliberalism use this discourse to articulate their interests in global market expansion (SCHOONMAKER, 2002).

By contrast, the major architect of the freedom discourse was Richard Stallman, who worked as a software developer at MIT's Artificial Intelligence Laboratory in the early 1980s. As has been discussed elsewhere (LESSIG, 2004; DRAHOS AND BRAITHWAITE, 2002; SCHOONMAKER, 2007), this was a time when IBM, Microsoft, and other corporations sought to extend copyright law to software. Technological developments made it possible to import software programs between different computing systems, creating an incentive for these firms to copyright particular programs and sell them as private property on the emerging software market.

In 1984, Stallman responded to these changes by seeking to protect what had been a commonplace freedom of software developers to access software source code to make changes to the programs and share their programs with each other. Since this freedom was threatened by corporate efforts to copyright software and render it proprietary, Stallman began a project to create an alternative software system compatible with Unix that would not be subject to this proprietary form of property. He called it the GNU Project, which stands for Gnu's Not Unix (GAY, 2002).

Stallman organized a community of programmers to contribute to the development of GNU, to apply their talent to "advancing the state of the art" rather than duplicating their efforts by programming separate proprietary systems (GAY, 2002, p. 34). He developed and articulated the 
freedom discourse as a central part of the broader process of organizing programmers around the development of GNU. In 1985, Stallman founded the Free Software Foundation (FSF), which was dedicated to promoting the freedom of computer users to access software source code so that they could run, improve, and release changes to programs to benefit their own work as well as the wider software community. Freedom was thus the guiding principle of the FSF and what Stallman called a "software-sharing community" (GAY, 2002, p. 15), where the hackers who wrote code shared software like cooks share recipes.

Stallman hacked copyright law to establish the legal basis for free software as a distinct form of property. In 1989, he copyrighted the GNU General Public License (GNU GPL). Thus, the GNU GPL license appeared as a juridical instantiation of the freedom discourse (JEAN, 2011, p. 117). The Preamble of this license was addressed to software users, stating that the license was

\begin{abstract}
intended to guarantee your freedom to share and change free software - to make sure the software is free for all its users [...] that you have the freedom to distribute copies of free software (and charge for this service if you wish), that you receive source code or can get it if you want it, that you can change the software or use pieces of it in new free programs; and that you know you can do these things (GAY, 2002, p. 195).
\end{abstract}

It is important to specify the user addressed in this Preamble: this user holds administrative rights over the computer that executes the program. There is thus a profound structural homology between the freedom discourse and the socio-technical environment of what is commonly understood as the personal computer era.

All software under the GNU GPL was copyrighted under existing copyright law. At the same time, however, the license undermined the usual proprietary restrictions of copyright law through what Stallman called the "method...[ of] copyleft" (GAY, 2002, p. 20) requiring all users of software under the GNU GPL to include access to the source code if they made modifications to the program. This requirement guaranteed that not only current, but future users of these software programs would have the freedom to change, copy and distribute the software. Through copyleft, Stallman and the Free Software Foundation thus inscribed the freedom discourse into copyright law. By institutionalizing this discourse through the legal workings of the copyright system, they prevented free software from being turned into proprietary software (GAY, 2002). This had key implications for the ability of users, developers and corporations to participate in the software market.

The freedom discourse was the foundation of the Free Software Foundation's (FSF) efforts to create free software as a new form of property, developed and used through a global software-sharing community. Free software thus provides an alternative to proprietary software, constructed on a number of levels. Technically, it offers a way to organize hackers and users into a community project of developing source code. Legally, 
copyleft and the GNU GPL employ existing law to ensure the users' free access to this code. At the level of the politics of globalization, free software communities represent an alternative to the logic of neoliberalism by basing their activities on the shared development of a common resource, rather than reinforcing private property rights of global corporations to enter markets around the world under the most profitable terms.

Some scholars have emphasized the individualistic, U.S.-centric qualities of the FSF's approach (COOMBE AND HERMAN, 2004; CHAN, 2004). This interpretation, however, has led them to underestimate the implications of the FSF's work to build a broader global community. Indeed, in the contemporary context where neoliberalism is the dominant form of globalization, building a software-sharing community has the potential to develop an alternative form of globalization from below. This potential is rooted in the development of free software as a new form of property based upon a complex form of community ownership, rather than strictly private ownership. As Srinivas (2006, p. 331) argues, “applying open source principles will prevent the privatization of what is in the public domain and will also enrich it." Srinivas (2006) emphasizes the importance of developing new forms of property, as well as alternative institutional arrangements, to protect a variety of forms of the global commons. Since 1996. French activists have engaged in such a process by building new institutional arrangements in their local context, in the form of a French free software community.

\section{FREE SOFTWARE IN FRANCE}

As discussed above, Sassen (2005, p. 54) argues that alternative forms of globalization involve the development of "transboundary public spheres" rooted in the connections between a range of local struggles and global networks. Over the last 17 years, French free software activists have engaged in a process of local struggle to develop one of the most vibrant free software communities in the world. It is important to note here that the nature of this community is not the same as those studied by the majority of free software researchers. Indeed, the French community is not organized around a particular free software project, such as Coleman's $(2005,2012)$ studies of Debian; nor is this a community of practice such as those studied by Hemetsberger (2009) or Villaroel and Taylor (2007). By contrast, the French community is organized around the freedom discourse, which articulates a set of universal value claims. At the same time, this community has strong connections to the Free Software Foundation (FSF) and is seeking to build relationships with communities in other European countries. This combination of national activism and international alliances suggests the possibility for the free software community to be one of the forms of globality, or transboundary public spheres, that Sassen (2005) theorizes.

The FSF is an international organization. However, most of its work 
has focused on developing the free software community in the United States. This occurred in part because, despite international conventions, each state can impose different licensing requirements that may conflict with the freedom discourse. By this logic, in order to develop a global free software community, activists in particular countries have worked to organize local communities to address the particular challenges there. The FSF does not provide an organizational structure to connect these local communities. As discussed above, however, it does articulate a freedom discourse about the value of free software to society; it also established free software as a new form of property through copyleft.

Inspired by the FSF, French activists sought to translate its approach to their national context. In 1996, a group of five French student activists founded the Association pour la Promotion et la Recherche en Informatique Libre (April), or the Association for Promotion and Research on Free Computing, which has become the major free software association in France. It is an associate organization of the Free Software Foundation France, which is a sister organization of the Free Software Foundation (FSF). The leader of these activists, Frédéric Couchet, recounted the process of founding April and developing the French free software community in an interview. As noted above, these events capture a kind of biography of what Couture and Proulx (2008) call "militants of code".

Couchet and the other co-founders of April were computer science students at the prestigious Paris 8 University. According to couchet (interview, 2009), "at Paris 8 the philosophy was that you were there to learn, so you could work on the machines and do roughly what you wanted". Students were encouraged to work together, and when the software involved was free software, they were able to install programs and run tests on the systems to look for potential problems. Thus they learned through practical experience how to develop the software and understand how it worked. Richard Stallman came to do a conference at the university and explained the FSF's approach to the French students. This exchange of ideas fostered the relationship between the students and the FSF, creating a space for further interaction and the growth of a transboundary public spanning France and the U.S.

Indeed, once Couchet finished his studies, his primary goal was to educate the French public about free software, like the FSF had done in the U.S. He stated,

And I thought [ ...] we could create an association with the goal of making people understand about free software, like the FSF did in the US. And in 1996 we created April with five students, without knowing concretely our objectives or how we would go about them; we just wanted to bring the understanding of free software to the people of France (Couchet, interview, 2009).

An early priority for the activists was to translate works about the Internet and free software into French. There were many writings that were only available in English, including the information about the FSF and its approach to free software. Translation work was thus germane to the 
construction of the transboundary public between France and the U.S. The April activities synchronized their work with the FSF and collaborated directly with Stallman, who Couchet (interview, 2009) described as "very, very happy" to support April's early efforts. This was thus the point from which the freedom discourse constituted a terrain of struggle over the construction of a transnational public. What was at stake, in effect, was simultaneously the local translation and diffusion of the freedom discourse to make it pertinent within the French context. Furthermore, this double movement of translation and transposition raises what Dagognet (2006) called the "transfer," where the delocalization or relocalization of a problem allows its contours to be more clearly and richly understood.

Couchet (interview, 2009) described the period from 1996-1998 as the first stage of developing the French free software community. Attention focused on local conditions in France, as the activists were "constantly adapting to the situation, slowly getting stronger" (Couchet, interview, 2009). April grew to about 15 or 20 members, most of them students from Paris 8. This was a period of learning about issues that were central in developing a free software community, including how to work with the media. Many journalists had little knowledge about free software; however, more became interested in it as the activists increased their public education work. After 1998, the activists had been able to contact more people with their message about the value of free software. They organized some larger actions, including a week-long event at the Science and Industry museum in Paris. There, they demonstrated how to use free software and educated people about its benefits. These kinds of educational events drew more involvement and interest in April's work. The activists also began working with companies to promote the use of free software in the private sector.

At this point, the game could have seemed about to be won. On April 19, 2001, the Socialist deputy Thierry Carcenac submitted a report to the French prime minister, entitled "For an Electronic Citizen's Administration". Among other issues, the report sought to engage the administration in "a strong but not obligatory movement toward free tools" (CARCENAC, 2001, p. 50). The political handover of power, combined with other factors, nevertheless led the report to fall through the cracks. Even if April had not been contacted during the drafting of the text, it can be seen as an indirect fruit of its work on public education during the first phase of its existence. Around this time, in part because of legal threats to free software in Europe and in France, April's freedom discourse shifted its audience from the general public to institutions.

In May 2001, neoliberal globalization asserted its influence over the French community when the European Union Copyright Directive (EUCD) was published (CANDIDATS.FR, 2007). The EUCD was shaped by the interests of transnational corporations that sought to impose digital rights management provisions on Internet users, including restrictions on the use of free software. The EUCD was the European implementation of the World Intellectual Property Organization (WIPO) Copyright Treaty ratified in 1996. 
It was thus the European equivalent of the Digital Millenium Copyright Agreement (DMCA) passed by the U.S. Senate in 1998. It exemplified what we call the proprietary discourse, which framed access to the Internet and software in terms of protecting the proprietary interests of corporations that have a legal right to defend their investments.

The publication of the EUCD sparked a second phase of political struggle to build the French free software community, where attention turned toward the community's relationship to its broader European context. April activists viewed the EUCD as a major threat to their work and mobilized to oppose it, providing local resistance to a global effort to assert the dominance of propriety ownership over software. At this critical juncture, the activists shifted into a new terrain and scale of organizing. Indeed, to make their struggles efficient at the European level, they had to contact other individuals and associations from Europe. Furthermore, in addition to working to educate people about free software, they fought to protect the legal possibility to use it. Couchet (interview, 2009) described this turning point: "It was necessary to act. This was really our first big project. We sent e-mails, we told people there were negative impacts for free software and it was time to act. [ ...] We did activities to get everyone to promote free software but also activities to defend it". This was a moment of transition in the community's development, because the activists recognized the importance of simultaneously pursuing two interrelated goals of promoting and defending free software. Under the political conditions in Europe, where powerful corporate interests opposed the use of free software, defending users' rights to access it was crucial.

April activists transformed and clarified their role in French software politics during this period. They engaged in a process of constructing and diffusing the freedom discourse as a narrative of power and knowledge within the French and larger European context. They employed a language of struggle within this discourse to emphasize the importance of defending free software as a new form of property against legislative efforts to mandate proprietary software. They targeted the European legal arena, sustaining the struggle against the European Union Copyright Directive (EUCD) and software patents (KARANOVIĆ, 2008, 2010) from 2001 to 2005. To do so, key April members got involved with the creation of the Free Software Foundation Europe (FSFE). FSFE was established March 10, 2001, from a German initiative that would not have seen the light of day without assistance from the French, according to an April report (APRIL, 2002). As the project had a federal vision, these key April members quickly created the French chapter of FSFE on April 19, 2001. The idea of being a "sister organization" of FSF (without any financial or organizational link), introduced by FSFE, was then reproduced in India and Latin America; it was also discussed in Japan. This transatlantic transfer of the freedom discourse reveals that this very discourse cannot bear fruit and succeed worldwide if it is not articulated effectively within the context of cultural and juridical realities. Indeed, only through such a process of cultural and juridical relevance can a transboundary public emerge. 
In November 2002, a group called the EUCD.INFO initiative was created within the French chapter of FSFE. Some April members were very active in this initiative. The French chapter of FSFE allocated $€ 10,000$ to fund the initiative, while simultaneously launching an appeal for donations to finance a legal team to work against the EUCD (EUCD.INFO, 2006). In this organizing effort, EUCD.INFO collaborated with organizations from Germany, England, Austria, Belgium, Denmark, Spain, Finland, France, Holland, Italy, Luxembourg, Norway, and Portugal. Furthermore, on April 26, 2004, the French chapter of FSFE was transformed into FSF France, a totally independent organization. This occurred in part because no other national FSFE chapter had appeared. Today, it is still the smallest FSF sister organization. This is further evidence that French free software activists are especially involved in the construction of a transboundary public through the freedom discourse. FSF France activities are very narrow, however, when compared to those of FSF or FSFE; FSF France only deals with juridical matters. Other FSF or FSFE activities are supported by April. There is thus an organic complementarity between these two French associations.

Struggles to promote the freedom discourse in the face of neoliberal pressures escalated in early December 2005, when the French bill "Copyright and Related Rights in the Information Society" (DADVSI) was proposed. DADVSI sought to institute the proprietary discourse by reforming French copyright law. It was designed to implement the principles of the EUCD in the French context, while also considerably extending them. DADVSI thus brought the conflicts between the proprietary and freedom discourses to a head, creating a terrain of struggle where April drew upon its network of relationships with the broader European transboundary public to organize within France.

The strengthening relationship between the French and broader European "militants of code" in their struggle against the proprietary discourse were highlighted at a discussion forum in Paris a few days after the DADVSI bill was introduced. April and EUCD.INFO participated in this forum on "Copyright in the Digital Era." Christophe Espern, one of the cofounders of EUCD.INFO, described DADVSI as a bill involving the rights of artists, composers and producers. The bill provided juridical protection for devices that monitored and traced Internet use. Such protections endangered the freedom discourse, posing serious implications for free software users and developers. Since monitoring and tracking devices are based upon a logic of secrecy, rather than the logic of transparency involved with free software, such devices make it impossible to use free software. DADVSI thus effectively denied users the right to choose free software systems.

April decided to expand its critiques of the bill to the "private copying" (copie privée) question, however, even if it does not belong to the same issue as free software. In France, as in most European Union countries, the "private copying right" is a juridical provision that allows to copy copyrighted work in the private sphere. Broca (2012, p. 172-176) 
emphasized this point with a quote from an interview he did with Couchet on the subject:

We have taken the bill globally, saying "there, we attack this bill in particular because it questions the private copying right." It was a public relation line for us, as well as a battle line. Actually, we didn't want to come out and say "the danger is for free software". We wanted to come out and say "there, the main danger is for private copying. What's more, free software is also in danger, so we will fight, too" (Frédéric Couchet, quoted in Broca, 2012, p. 172, our translation).

This "rise in generality" (BOLTANSKI AND THÉVENOT, 1991) of the freedom discourse shows the will to place free software as the central, but not exclusive, matter of digital freedoms. French activists still used the semantic field of the freedom discourse to denounce the DADVSI bill as a freedom-destroying bill.

Indeed, passage of the DADVSI bill threatened to criminalize many commonplace activities, such as downloading music; copying CDs; playing DVDs with software not authorized by the DVD producer; or using software that made it possible to circumvent copy protection. The last activity was especially worrisome, since it could apply to a wide range of popular software programs, including operating systems that could potentially be modified to circumvent copy protection even if they were not initially designed to do so. Any software developer might thus be targeted as liable for copyright infringement. Indeed, DADVSI identified everyone who bypassed a monitoring or tracking device as infringing copyright. Those who made files available for downloading illegally would be subject to fines of up to $€ 150$, while those who simply engaged in illegal downloads would be subject to fines of $€ 38$. Producers and distributors of software that allowed such practices would face the stiffest penalties, including up to three years in prison or a fine of $€ 300,000$. DADVSI thus sought to institutionalize the proprietary discourse by imposing digital rights management on all software users and to criminalize both the production and use of software programs that allowed users to circumvent copy protections (ESPERN, 2005; PAUL, 2005; BANGEMAN, 2006a; BANGEMAN, 2006b).

Espern (2005) highlighted the conflict between the ways that the freedom and proprietary discourses understood the rights involved with consuming commodities in digital form. From the point of view of the freedom discourse, he explained, "when you buy a CD, you have every right to copy it. With these technical mechanisms [ in the DADVSI bill], you cannot do this. It poses a problem in terms of innovation, in terms of free trade". For individual users, these problems are rooted in the fact that the monitoring and tracking software makes it not only technically impossible, but illegal, for them to use free software to search out solutions to their problems with software programs. Their freedom to choose whatever form of software they want is restricted to protect corporations' proprietary interests. For small firms, it makes them "hesitant to innovate...hesitant to compete with the big firms and try to destabilize them, to take their part of 
the market" (ESPERN, 2005). Indeed, small firms hesitated to compete with large companies that employed teams of lawyers who could initiate legal action against competitors on the grounds of violating DADVSI.

The DADVSI bill was extremely controversial. Indeed, it sparked opposition from groups that rarely agreed on issues of software politics, including the Free Software Foundation (FSF) and the Business Software Alliance (BSA). The BSA's members included major U.S. software firms like Microsoft, Apple, Intel, HP, and IBM. It generally worked to promote copyright protection and combat what it viewed as problems of software piracy. In the case of DADVSI, however, the measures intended to protect copyright had serious implications for proprietary software companies whose systems could be judged as contributing to copyright violation (PAUL, 2005).

Specific amendments to the DADVSI bill were particularly problematic for free software proponents. These amendments were designed to impose unprecedented forms of digital rights management. They required suppliers of electronics equipment or software to include technical measures to prevent users from copying and redistributing digital content or software programs. Free software users and developers would thus be presumed guilty of violating the law, since their software would not include such provisions (ESPERN, 2005). The FSF viewed this as an effort by French media corporations to force free software developers to adopt proprietary licenses. These corporations enjoyed the support of the French SACEM, which plays a similar role in France as the Recording Industry Association of America plays in the U.S. A SACEM representative stated that the organization supported an amendment to the DADVSI bill that, if passed, would allow them "'to sue free software authors who will keep on publishing source code'" (FSF FRANCE, 2005). A representative from the Ministry of Culture added that free software authors would be required to change their licenses.

Days after DADVSI was published in December 2005, French free software activists extended their struggle against these efforts to criminalize their community form of property. EUCD.INFO launched a campaign, "No to the DADVSI bill," in which April participated fully. They argued that DADVSI favored multinational corporations and virtually ignored developers and users of free software; Internet users in general; librarians; artists or consumer associations. In organizing against DADVSI, activists stressed the importance of including this broader range of interests in discussions about the bill. They launched a campaign to gather signatures on a petition demanding that these groups be allowed to participate in a substantive discussion of the bill's implications. By August 2006, activists had gathered 173,628 individual signatures. Equally important, almost 1,000 organizations signed the petition, including 230 businesses whose activities were threatened by the bill (EUCD.INFO, 2005; ESPERN, 2005). Despite these efforts, the DADVSI bill was signed into law on August 3, 2006 (APRIL, 2009).

French software activists were thus unsuccessful at stopping DADVSI from becoming law. Their years of organizing, however, sparked a 
dramatic growth in membership and an expansion of the public knowledge about issues of free software in the country. As shown in Figure 1, April's membership grew from 192 in 2004 to 253 in 2005 and 449 in 2006. As the activists continued organizing after the passage of the DADVSI law in 2006, April's membership quadrupled to 1796 in 2007. This increase was largely due to the increasing prominence of April's activist work, as well as the launch of a membership campaign in 2007. The activists successfully used such campaigns to grow April's membership from about 3475 members in 2008 to 5381 in 2009 (APRIL, 2007).

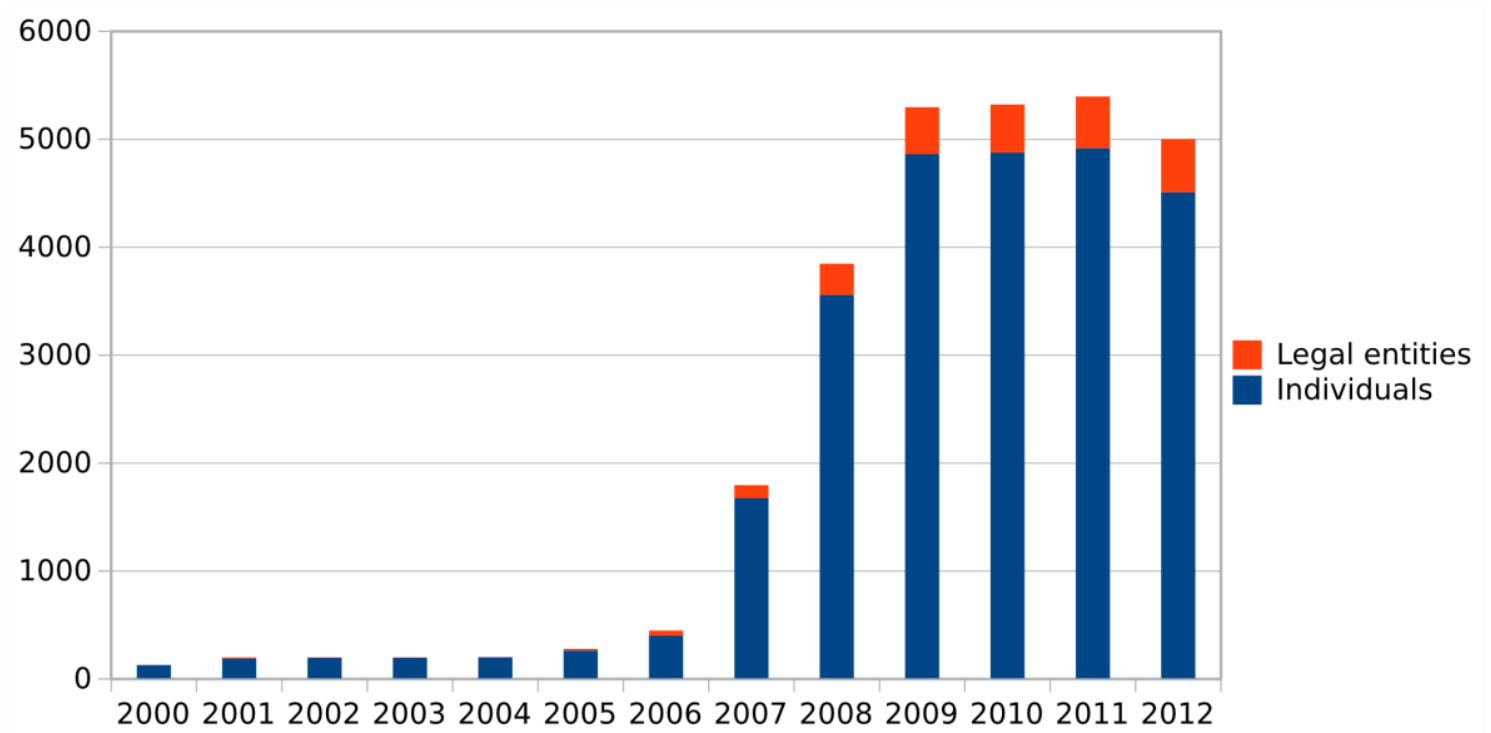

Figure 1: April's membership from 2000 to 2012

Source: source: http://www.april.org/rapports-moraux-de-lapril

This rise in the number of members can also be explained by April's proactive approach. For example, on May 19, 2007, April launched a membership campaign at an event featuring Richard Stallman as a key speaker. This revealed that the rise in the number of members was mostly due to a broader acknowledgement of April's usefulness and legitimacy as bearer of the freedom discourse within the French free software movement.

\section{CONCLUSION: FREE SOFTWARE AND GLOBALIZATION FROM BELOW}

The French free software case poses lessons to understand the prospects for developing alternative forms of globalization from below. April made a major contribution to building such an alternative by not only establishing a free software community in France, but by staking out the political defense of free software as a key part of its mission. Equally important, in the process of building and defending free software in France, April maintained a strong relationship with the FSF. Indeed, this relationship forms the basis for April to extend the FSF as what Sassen (2005, p. 54) calls a "[ form] of globality centered in multiple localized types of struggles and agency". Free software activists in France and the U.S. employed the freedom discourse to build transboundary publics rooted in the promotion and defense of free software as a complex form of community-based property. 
For example, Anton Chastain, a member of April's board who has been involved with the association since the early years at Paris 8, described its relationship with Stallman and the FSF in an interview. He noted that when Stallman came to France to meet with April activists, he began his presentation by saying "I can summarize free software in three words: liberté, égalité, fraternité! It fits very well in French, evidently". By drawing upon the French values of freedom, equality and brotherhood, as well as by speaking fluent French, Stallman used the freedom discourse to highlight how the ethic of free software resonated within the French cultural context. In turn, Chastain drew upon this discourse to extend the parallel between the philosophy of free software and French culture. He stated that free software involves "the freedom to share. And equality is that there is nobody who will say to you, 'you must do this, but not that'. And brotherhood is that there is no barrier between the developers and the users. For me, this is truly the ethic of free software" (Chastain, interview, 2009).

April's local struggles in France have thus been globally connected to the FSF to create a transboundary public. These associations share a discursive and political approach to the project of promoting free software as a community-based form of property that contributes to the digital commons. Indeed, April has undergone a process that Sassen (2005, p. 55) described as "localized entities becom[ ing] microenvironments with global span". Through such a process, local organizations or users become conscious of "the recurrence of these types of actions in locality after locality, thereby contributing to the reshaping of these global networks for communication into global zones for interactivity" (SASSEN, 2005, p. 55). European alliances to fight the EUCD are an example of such a process, as are continuing efforts to oppose the extension of digital rights management provisions that threaten free software.

Indeed, we do not attempt to analyze all of the French activist struggles during the first decade of the $21^{\text {st }}$ century. In particular, we did not mention the struggle against software patents and against the HADOPI bill (High Authority for Transmission of Creative Works and Copyright Protection on the Internet). For an analysis of these two cases, the reader may consult the excellent work of Karanović $(2008,2010)$ and Broca (2012). By contrast, we provide a conceptual framework that may be applied to understand other struggles, highlighting how activists employ the freedom discourse to forge alternative forms of globality. The struggles we analyze here thus reveal the evolution April has undergone during its first ten years of existence. Certainly, the expansion of its scope of action, by getting involved in European politics, occurred in parallel with an expansion of the freedom discourse to more general digital freedoms through the multiplication of specialized associations. For example, we have seen how the EUCD directive led to the creation of FSF France, which supported the freedom discourse in explicitly juridical terms. In 2008, after the DADVSI failure, key members of April worked to expand the scope of activism by applying the freedom discourse to related spheres. These 
activists, some of whom were part of the FSF France and the EUCD.INFO initiative, founded La Quadrature du Net, which focuses its work on the fight for net neutrality. In English, La Quadrature du Net translates as Squaring the Net, a metaphor that alludes to the impossibility of having an Internet that is "squared," or limited by restrictions on the free exchange of information by all of its users. Significantly, in an articulation of the freedom discourse within the realm of net neutrality, Squaring the Net's motto is "Internet and freedoms." Although French, it has strong links with several European counterparts, thus extending the creation of a transboundary public. Another key organization engaged in this work is Regards Citoyens, or Citizens' Gaze. Founded in 2009 by Tangui Morlier, another key member of April who later became its president from 2010 until 2012, this association promotes political transparency through the use of public data and creation of applications. To us, these examples reveal that the fluidity of the freedom discourse is central to the constitution of transboundary publics. It shows how they can be difficult to capture, since both their spatial and narrative dimensions are fluctuating.

Moreover, April's collaboration with the FSF to build a French free software community requires what Sassen (2005, p. 75) calls a "reconceptualization of the local" where globalization involves the development of more than just institutional spaces. The French case highlights how globalization can include "powerful imaginaries enabling aspirations to transboundary political practice" (SASSEN, 2005, p. 75), even when the actors are rooted in a particular local context. This was certainly the case for Couchet and the other activists that founded April by applying the FSF's approach to their own local conditions. The FSF's work caught their imaginations and provided a model for what was possible; however, the April activists put those ideas into practice in unique ways adapted to the French context. The freedom discourse was a central part of this process, since it provided a narrative of power and knowledge about how to understand free software as a distinct form of property, as well as the interests at stake in both promoting and defending it.

Equally important, European conflicts over the EUCD illuminate the importance of interconnected forms of spatiality in struggles to create alternative forms of globality. April and its European allies organized to influence the political spatiality of the state, as they sought to construct alternative forms of spatiality of the market to promote and defend the production and use of free software.

French software politics thus hold significance for understanding the process of developing alternative forms of globalization from below. This process involved transboundary political practice where activists in the U.S. and France shared a common discourse and commitment to building free software as a new form of property rooted in a complex mode of community ownership. Equally important, this alternative was forged through an ongoing process of political struggle to defend the conditions for developers and users to access this new form of property. April's struggles against the EUCD and DADVSI reveal the importance of such 
ongoing political action. The development of the French free software community contributes to the global development of a digital commons, where users and developers from around the world can access free software as a new form of property. Nonetheless, ongoing threats to dismantle this form of property through legislation reveal the importance of continued activism to build transboundary publics that span the local and the global in creative, transformative ways.

\section{REFERENCES}

APRIL. Position on the Dadvsi Law, 2009. Available at: http://www.april.org/en/position-dadvsi-law. Accessed: 3 July 2009.

APRIL. Rapport moral sur l'activité de I'April 2001, 2002. Available at: http://www.april.org/articles/divers/rapport-moral-2001.html\#ToC10.

Accessed: 3 July 2009.

APRIL. Rapport moral sur l'activité de l'April en 2007, 2007. Available at: http://www.april.org/articles/divers/rapport-moral-2007.html\#ToC2.

Accessed: 3 July 2009.

BANGEMAN, Eric. French legislation might chase iTMS out of the country. Ars Technica, 2006a. Available at: http://arstechnica.com/old/content/2006/03/6371.ars. Accessed: 30 July 2009.

BANGEMAN, Eric. French parliament passes DRM bill. Will Apple bolt? Ars Technica, 2006b. Available at: http://arstechnica.com/old/content/2006/03/ 6428.ars. Accessed: 29 July 2009.

BERNAL, Victoria. Diaspora, cyberspace and political imagination: the Eritrean diaspora online. Global Networks. v. 6, n. 2, p. 161-179, 2006. http://dx.doi.org/10.1111/j.1471-0374.2006.00139.x

BOLTANSKI, LUC; THÉVENOT, Laurent. De la justification : les économies de la grandeur. Paris: Gallimard, 1991.

BOUQUET, Christian. La mondialisation est-elle le stade suprême de la colonisation? Les Cahiers d'Outre-Mer. Revue de géographie de Bordeaux. v. 60, n. 238, p. 185-202, 2007.

BOYLE, James. The second enclosure movement and the construction of the public domain. Law and Contemporary Problems, v. 66, n. 1-2, p. 3374, 2003.

BROCA, Sébastien. L'utopie du logiciel libre. La construction de projets de transformation sociale en lien avec le mouvement du free software. 2012. Thesis - Université Panthéon-Sorbonne, Paris, 2012.

CANDIDATS.FR. Principe des mesures techniques et de la protection juridique associée, $2007 . \quad$ Available at: http://www.candidats.fr/index.php/2007/01/27/11-principe-des-mesurestechniques-. Accessed: 20 June 2009.

CARCENAC, Thierry. Pour une administration électronique citoyenne :

18 Revista Eletrônica de Sistemas de Informação, v. 13, n. 2, May-Aug 2014, paper 3 (2) doi:10.5329/RESI.2014.130200* 
contributions au débat. Paris: Rapports Officiels, 2001. Available at: http:// www.ladocumentationfrancaise.fr/rapports-publics/014000291/index.shtml.

Accessed: 15 April 2013.

CASTELLS, Manuel. The information age: economy, society and culture. The rise of network society. Oxford: B. Blackwell, 1996.

CHAN, Anita. Coding free software, coding free states: free software legislation and the politics of code in Peru, Anthropological Quarterly, v. 77, n. 3, p. 531-45, 2004. http://dx.doi.org/10.1353/anq.2004.0046

COLEMAN, Gabriella. Coding freedom: the ethics and aesthetics of hacking. Princeton: Princeton University Press, 2012.

COLEMAN, Gabriella. Three ethical moments in Debian. 2005. Thesis - New Brunswick : Rutgers, Center for cultural analysis, 2005.

COOMBE, Rosemary J.; HERMAN, Andrew. Rhetorical virtues: property, speech, and the commons on the world-wide web, Anthropological Quarterly, v. 77, n. 3, p. 559-74, 2004. http://dx.doi.org/10.1353/anq.2004.0037

COUTURE, Stéphane; PROULX, Serge. Les militants du code. In: COUTURE, Stéphane; PROULX, Serge; RUEFF, Julien (eds). L'Action communautaire québécoise à l'ère du numérique. Québec: Presses de l'Université du Québec, 2008.

DAGOGNET, François. Philosophie du transfert. Paris: Michalon, 2006.

DOUEIHI, Milad. La grande conversion numérique. Paris: Seuil, 2008.

DRAHOS, Peter; BRAITHWAITE, John. Information feudalism: who owns the knowledge economy? London: Earthscan Publications, 2002.

ESPERN, Christophe. Le projet de Ioi DADVSI. Presentation at discussion forum Le droit d'auteur à l'ère du numérique. I'Agora du Carrefour numérique à la Cité des Sciences et de I'Industrie de la Villette, Paris, 2005. Available at: http://carrefour-numerique.citesciences.fr/live/dadvsi_textes.html\#eucd. Accessed: 13 June 2009.

EUCD.INFO. La loi Dadvsi a été publiée le 3 août 2006 au journal officiel. 2006. Available at: http://www.eucd.info/119.shtml. Accessed: 13 June 2009.

EUCD.INFO. Pétition demandant le retrait de l'ordre du jour parlementaire du projet de Ioi DADVSI. 2005. Available at: http://eucd.info/petitions/index.php? petition=2. Accessed: 16 June 2009.

FOUCAULT, Michel. The history of sexuality. Volume l: an introduction. New York: Vintage Books, 1978.

FSF FRANCE. French government lobbied to ban free software. 2005. Available at: http://www.fsffrance.org/news/article2005-11-25.en.html. Accessed: 31 July 2009.

GAY, Joshua (ed.). Free software, free society: selected essays of Richard M. Stallman. Boston: GNU Press, 2002.

(2) Revista Eletrônica de Sistemas de Informação, v. 12, n. 3, May-Aug 2014, paper 319 doi:10.5329/RESI.2014.1302003 
GIRAUD, Pierre-Amiel. Le voyage de militants aux rencontres mondiales du logiciel libre : pèlerinage ou mission? Cahiers ADES. n. 10, forthcoming.

GIRAUD, Pierre-Amiel. Les RMLL, un haut lieu mobile du libre francophone. In: MASUTTI, Christophe and PALOQUE-BERGES, Camille (eds). Histoires et cultures du libre. Des logiciels partagés aux licences échangées. Paris: Framasoft, 2013.

GRATALOUP, Christian. Géohistoire de la mondialisation : le temps long du monde. Paris: Armand Colin, 2007.

HEMETSBERGER, Andrea; REINHARDT, Christian. Collective development in open-source communities: an activity theoretical perspective on successful online collaboration. Organization Studies, v. 30, n. 9, p. 987-1008, 2009. http://dx.doi.org/10.1177/0170840609339241

JEAN, Benjamin. Option libre: du bon usage des licences libres. Paris: Framasoft, 2011.

KARANOVIĆ, Jelena. Contentious Europeanization: the paradox of becoming European through anti-patent activism. Ethnos. v. 75, n. 3 , p. 252-274, 2010.

KARANOVIĆ, Jelena. Sharing publics: democracy, cooperation, and free software advocacy in France. 2008. Thesis - New York University, 2008.

KARIM, Karim. Mapping diasporic mediascapes. In: KARIM, Karim (ed). The media of diaspora. London: Routledge Press, 2003.

KELLNER, Douglas. Theorizing globalization. Sociological Theory, v. 20, n. 3, p. 285-305, 2002. http://dx.doi.org/10.1111/0735-2751.00165

KELTY, Christopher. Two bits: the cultural significance of free software. Durham: Duke University Press 2008. http://dx.doi.org/10.1215/9780822389002

LESSIG, Lawrence. Free culture: how big media uses technology and the law to lock down culture and control creativity. New York: Penguin Press, 2004.

LUSSAULT, Michel. L'homme spatial. Paris: Seuil, 2007.

MÉDARD, Jean-François. Le modèle unique d'État en question. Revue internationale de politique comparée, v. 13, n. 4, p. 681-696, 2007.

NOONAN, Douglas; BAKER, Paul; MOON, Nathan. Open source software potential index (OSPI): development considerations. Red Hat/Georgia Tech OSPI project, 2008. Available at: http://www.redhat.com/about/where-isopen-source/activity/. Accessed: 5 May 2010.

PAUL, Ryan. France's proposed copyright reforms are more draconian than the DMCA, Ars Technica, 2005. Available at: http://arstechnica.com/old/ content/2005/12/5729.ars. Accessed: 30 July 2009.

RICOEUR, Paul. Temps et récit. Paris: Seuil, 1983.

SASSEN, Saskia. Electronic markets and activist networks: the weight of 
social logics in digital formations. In: LATHAM, Robert and SASSEN, Saskia (eds). Digital formations: IT and new architectures in the global realm. Princeton: Princeton University Press, 2005. http://dx.doi.org/10.1515/9781400828593

SASSEN, Saskia. Territory, authority, rights: from medieval to global assemblages. Princeton: Princeton University Press, 2008.

SCHOONMAKER, Sara. Globalization from below: free software and alternatives to neoliberalism. Development and Change, v. 38, n. 6, p. 999-1020, 2007. http://dx.doi.org/10.1111/j.1467-7660.2007.00462.x

SCHOONMAKER, Sara. High-tech trade wars: U.S.-Brazilian conflicts in the global economy. Pittsburgh: University of Pittsburgh Press, 2002.

SRINIVAS, Krishna Ravi. Intellectual property rights and bio commons: open source and beyond. International Social Science Journal, v. 58, n. 188, 2006.

VILLARROEL, J. Andrei.; TAYLOR, John E. Managing competing communities of practice: the impact of open source and knowledge-bridging on systemlevel learning. In: NAACSOS Annual Conference. Atlanta, 2007. 